Informatika i sistemy upravleniya. - 2017. - No. 4(54). - P. 12-19.

\author{
Abakumov A.I. (abakumov@iacp.dvo.ru) \\ Institute of Automation and Control Processes
}

\title{
WHAT MUST BE THE FISHERY MODE?
}

The marine commercial fishery often takes place in conditions of considerable and rapid changes of abundance. The paper shows that population dynamics is leveled by structure of population and is smoothed over when it comes to fishery, especially an optimum one. The optimum fishery mode can be chosen from a simple class of constant intensity control. Such mode differs a little from the optimum one in efficiency in a wide class of piecewise intensity control.

Keywords: optimization, differential equations, fish population, abundance dynamics, fishery, mathematical modeling.

DOI: $10.22250 /$ isu.2017.54.12-19

For citation:

Abakumov A.I. WHAT MUST BE THE FISHERY MODE? // Informatika i sistemy upravleniya. 2017. - No. 4(54). - P. 12-19. 